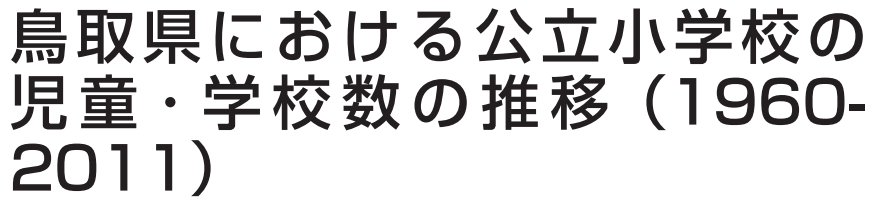

鳥取県における公立小学校の 2011)

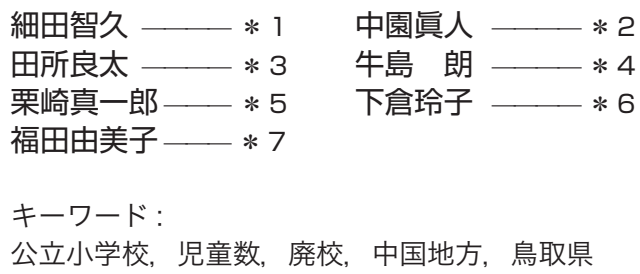

Keywords:

Public elementary school, Pupil numbers, Closed school, Chugoku region, Tottori prefecture

\title{
CHANGES IN THE NUMBER OF ELEMENTARY SCHOOLS AND PUPILS FROM 1960 TO 2011 IN TOTTORI PREFECTURE
}

Tomohisa HOSODA - $* 1$
Ryota TADOKORO- $* 3$
Shinichiro KURISAKI - *5
Yumiko FUKUDA $-* 7$

We developed a database of the number of public elementary schools and their pupils in Tottori. This paper aims to explain the changes in pupil numbers and resulting schools closures. From 1960 to 1975 the number of children fell by half and that forced many schools to shut down, but branch schools thrived to some extent. After that there are no major changes until 1999. However the amalgamation and reorganization of schools accelerated after 2000 as the large scale merging of municipalities took place. We classified and analyzed cities and towns by the changes of number of schools in them.

\section{1. 序論}

中国地方の中山間地域や島嶼地域では、监童数減少による小中学 校の統廃合が進行しており、過疎化・高齢化と学校の廃校により、将 来的なコミュニティの持続が危ぶまれる地域を多数抱えている。特 に山陰地方の鳥取県・島根県は他県に比べても児童数減少が激しく、 統合による運営の合理化を目指す動きと共に、廃校施設の活用にも 苦慮している自治体が多くみられる ${ }^{1)}$

統廃合に関する既往研究には、廃校の発生要因を分析した研究 ${ }^{2)}$ 、 統廃合と廃校舎の利活用決定プロセスの関連を考察した研究 ${ }^{3)}$ 、廃 校のある地域属性の特徵と再利用に関寸る研究 ${ }^{4)}$ がある。廃校の施 設利用に関しては、廃校施設の発生状況と転用用途の研究 ${ }^{5)}$ や、公 立小中学校施設の運用状況に関する研究 ${ }^{6)}$ 、統廃合後の児童数の推 移や学校行事の継承により学校と地域の結びつきを捉えた研究等 7 ) があるが、過疎化が進行する広範な農山漁村地域を抱え、人口減少 が顕著な地方県全域を対象とした、過去 50 年間にわたる時系列的な 廃校推移に関する蓄積は少ない。

また、我国の自治体範囲や学校施設配置は、これまで政策的な要 因によってたびたび変更されてきた ${ }^{8)}$ 及ひ注 11 。览童数の減少によっ て学校施設の効率的配置や廃校舎の地域利用等が進む中で、これら の計画的な提言のためには、地域と学校区の成り立ちそのものを紐 解いて議論を進める機会がより一層増えると考えている。そこで、 中国 5 県における公立小中学校の児童・生徒数と統廃合の動きを順 次報告し、横断的な一連の研究とする予定注 2) で、山口県公立小学 校に関しては本報告集で報告済みである ${ }^{9)}$ 。

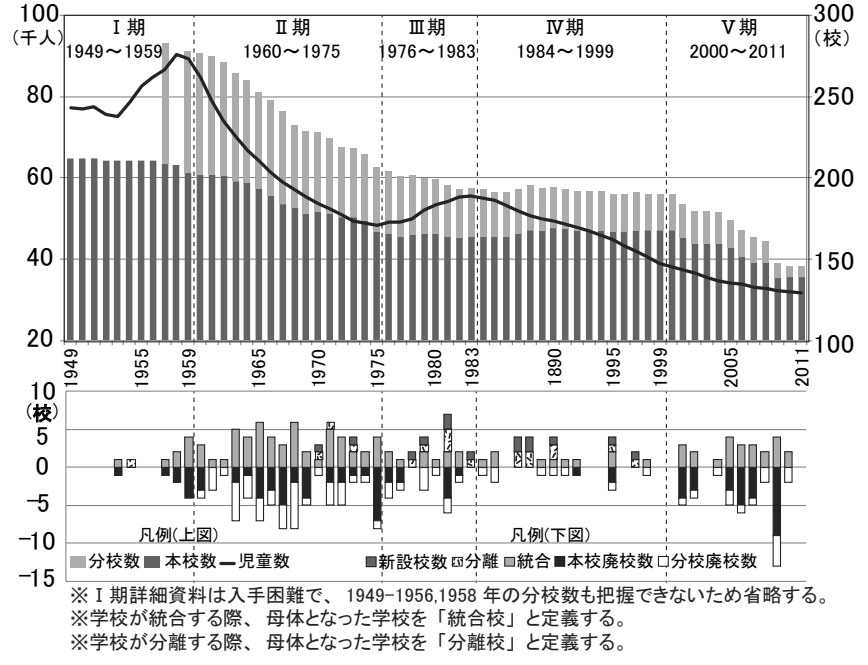

図 1 学校・児童・廃校数の推移と時期区分

本論では、鳥取県を対象に公立小学校 1 校毎の览童数、新設・廃 校に関するデータベースを 1950 年代から 2011 年まで時系列的に構 築し、児童数推移をもとに時期区分を行い、1960 年時点の旧市町 村区域を分析単位とし、都市地域と農山漁村地域における自治体所 管学校数と廃校状況の関係を整理する。次いで時期毎の児童数増減 率・学校増減率を指標に自治体の児童数・廃校数推移形態の類型化を 行うことで、自治体特性を踏まえた廃校の時期的・地域的推移の特 徵を明らかにすることを目的とする。この自治体類型と廃校数の関 係は、中国 5 県を横断的に見る際の分析視点になると考えている。

\footnotetext{
米子工業高等専門学校 准教授・博士 (工学)

( ( 683-8502 鳥取県米子市彦名町 4448)

山口大学大学院理工学研究科 教授・工博

山口大学大学院理工学研究科 大学院生

山口大学大学院理工学研究科 助教・博士 (工学)

広島工業大学 准教授・博士 (工学)

呉工業高等専門学校 准教授・博士 (工学)

広島工業大学 教授・博士 (学術)
}

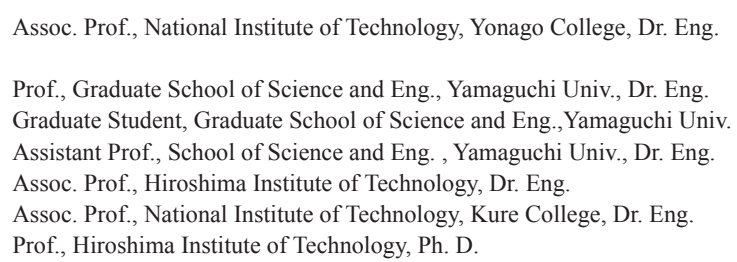




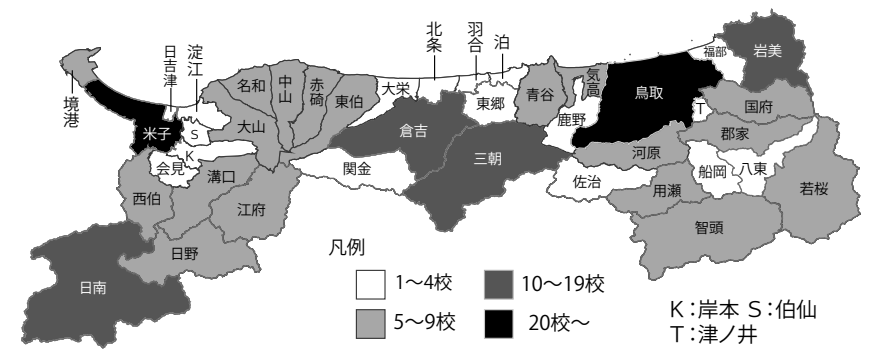

図 2 旧市町村別学校数 (1960)
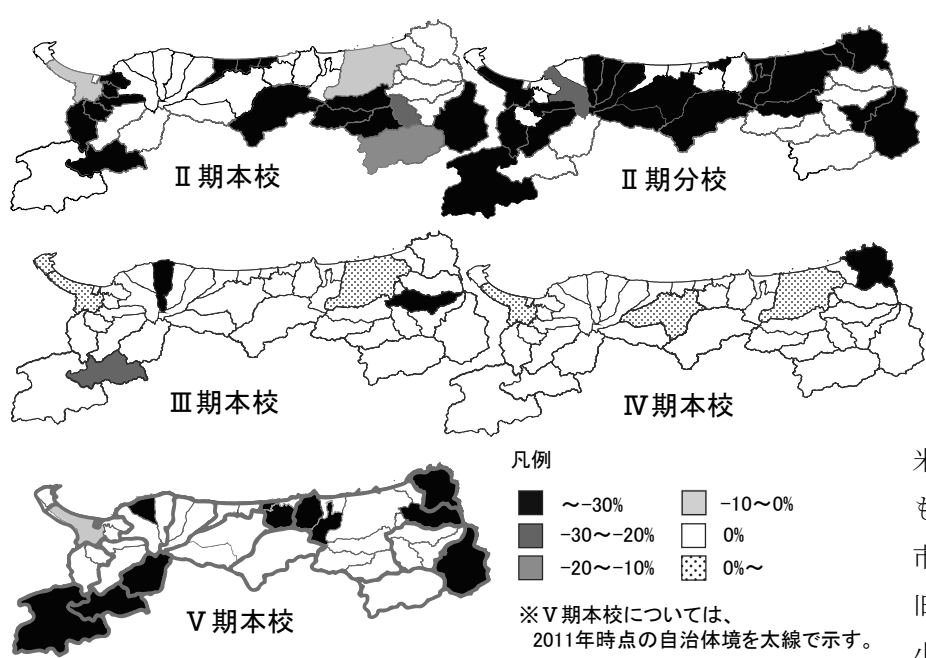

凡例

図 3 各自治体の時期別学校増減率

分析に使用した資料は鳥取県教職員録 (1949-1959) 注 3 )、教育行 政便覽(1960-2011) 注4) である。

\section{2. 鳥取県における時期区分別児童 - 公立小学校数の推移（図 1)}

鳥取県の学校・児童・廃校数の推移を図 1 に示寸注 5)。その際、 児童数の経年的推移をもとに I 期から V 期に時期区分を行っている。 第 1 次ベビーブームの影響による児童増加が著しい I 期 (1949-1959 年) は、廃校・新設・統合いずれも少ない。一方、ベビーブーム後 の児童が急激に減少する II 期(1960-1975) では、75 校と廃校が多く、 統合も 53 校存在し、大幅な児童数減少が影響して学校の統廃合が 進んでいる。その後、第二次ベビーブームによる児童数増加がみら れるIII期 (1976-1983) では、新設校 5 校に対し廃校が 16 校存在し、 ゆるやかに廃校が進行している。IV期(1984-1999)では、再び児童 数の減少が起こり、本校で 3 校、分校で 7 校の廃校が存在する。一 方，新設校も 7 校あり学校数の減少は少ない期間となっている。平 成の大合併以降の V 期 (2000-2011) は、児童減少はIV期と同様の水 準で継続して進行している。しかし、この期間には廃校数 42 校、 統合 24 校と大きな值を示しており、これは市町村合併が行われた 際に小学校の再編が進められたものと推察される。分校数に限って 見ると、II 期中に半減しているが、IV期まで比較的緩やかに減少し ており、減少が急な山口県とは異なる特徵が見られる。

\section{3.旧市郡部における自治体の廃校状況}

\section{1 旧市町村の学校数（図 2)}

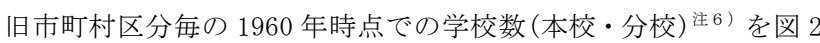
に示す。市部では郡部に対して多くの学校を所管し、特に鳥取市と
表 1 旧市郡部における時期別廃校状況

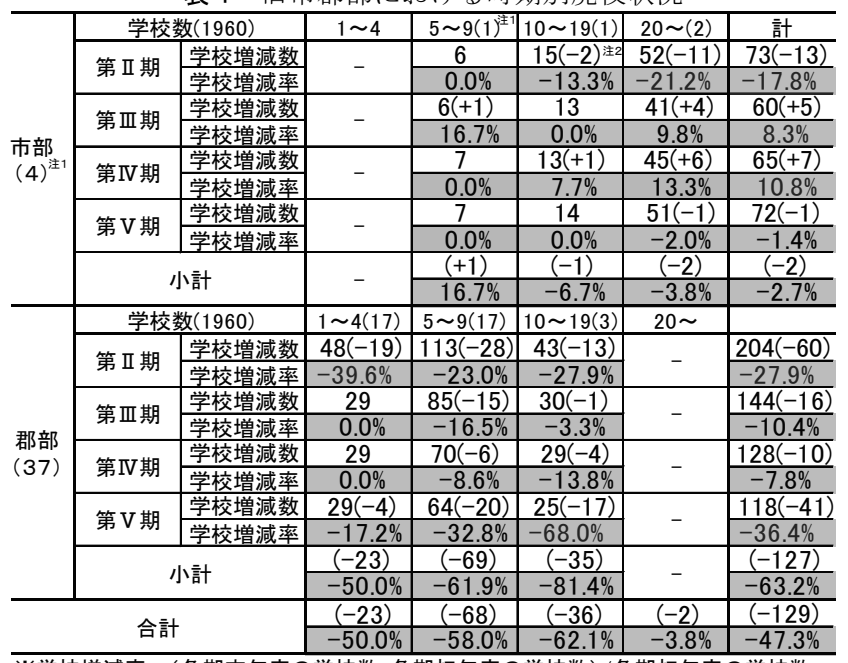

※学校増減率 $=($ 各期末年度の学校数 - 各期初年度の学校数 $) /$ 各期初年度の学校数 ※小計·合計学校増減率 $=(2011$ 年度の学校数 -1960 年度の学校数 $) / 1960$ 年度学校数 ※注1)括弧内の数值は自治体数を示す。

※注2) 表中の学校数は期始の学校数、括弧内の数值は各期の学校増減数を示す。

米子市は 20 校を超える小学校を所管している。ただし全 4 市の中で も境港市は 6 校と所管する学校数が少なく、これは地域面積が狭く 市人口も 3.5 万人と最も少ないことに起因する。 37 町村が存在する 旧郡部では、1〜4 校の小学校を所管寸る町村が 17 地区、 5 ～校の 小学校を所管する町村が 17 地区と各町村が所管する学校数は少な い。10１9 校の小学校を所管する地域も存在するが、三朝町のよう に 16 校中 9 校が分校で、本校は 7 校と少ない。これは、1953 年の 5 村合併によって誕生したことで、行政区域が中山間地域を含む広域 にまたがっており、各地区の小学校が残っていたことによる。

1960 年時点で鳥取県が所管する公立小学校 277 校のうち、1〜4 校を抱える地域に存在する小学校が 48 校、5９ 校を抱える地域に 存在する小学数が 119 校、10〜19 校を抱える地域が 68 校と小〜中 規模の地域に存在する学校が多くを占めている (表 1 学校数参照)。

\section{2 旧市郡部における時期別廃校状況（表 1)}

次に旧市町村における時期別廃校状況を市部と郡部に区分し表 1 に示す。市部では II 期の学校増減率が-17. 8\%と最も高い負の值を示 している。III期、IV期は廃校が見られず、それぞれ学校増減率が 8. 3\%、 $10.8 \%$ と学校数の増加が生じている。V 期も市部全体で学校数減少は 1 校にとどまり、学校増減率は-1. 4\%と大きな変化は生じていない。 郡部では、II 期の学校増減数 ・ 学校増減率ともに高い負の值を示 しており、1〜4校の地域では 19 校減少、5９校の地域では 28 校減 少、10 19 校の地域では 13 校減少と、どの地域でも学校数の減少 が進んでいる。特に 1 4 校を所管する地域では学校増減率が-39.6\% と極めて高い。また、II 期全体でも学校数減少が 60 校、学校増減率 が-27. $9 \%$ と、市部の学校数減少 13 校、学校増減率 $-17.8 \%$ と比心゙、学 校数減少の傾向が顕著である。III期においても市部で学校数が増加 しているのに対し、郡部では減少の傾向を示しており、特に、5〜9 校を抱える地域での学校数減少が 15 校、学校増減率が-16.5\% 高い 值を示す。IV期も III期と同様に、5～9, 10〜19 校を抱える学校にお いて学校数の減少が見られる。ただし、1〜 4 校の地域では、この間 廃校は発生していない。V期では、1〜4 校の地域で 4 校が減少、5 ～9 校の地域で 20 校が減少、10〜19 校の地域で 17 校が減少と、再 び各地域において学校減少が顕著に表れる。郡部全体では、計 127 
表 2 児童・学校増減率推移を指標とした自治体類型結果

\begin{tabular}{|c|c|c|c|c|c|c|c|c|c|c|c|c|c|}
\hline \multirow[b]{2}{*}{ 類型 } & \multirow[b]{2}{*}{$\begin{array}{c}\text { 自治体 } \\
\text { 数 }\end{array}$} & \multirow{2}{*}{$\begin{array}{c}\text { 本校数 } \\
\text { 平均 } \\
(1960)\end{array}$} & \multirow{2}{*}{$\begin{array}{c}\text { 学校数 } \\
\text { 平均 } \\
(1960)\end{array}$} & \multicolumn{5}{|c|}{ 学校増減率(\%) } & \multicolumn{4}{|c|}{ 児童増減率(\%) } & \multirow[b]{2}{*}{ 樹形図 } \\
\hline & & & & $\begin{array}{l}\text { II 期 } \\
\text { 本校 }\end{array}$ & \begin{tabular}{|l} 
II 期 \\
分校
\end{tabular} & $\begin{array}{l}\text { III 期 } \\
\text { 本校 }\end{array}$ & $\begin{array}{l}\text { IV 期 } \\
\text { 本校 }\end{array}$ & $\begin{array}{l}\mathrm{V} \text { 期 } \\
\text { 本校 }\end{array}$ & II 期 & III 期 & IV 期 & $\mathrm{V}$ 期 & \\
\hline 都市型a & 1 & 25.0 & 30.0 & -4.0 & -100.0 & 4.2 & 16.0 & 0.0 & -29.0 & 20.8 & -23.8 & -12.0 & \\
\hline 都市型b & 2 & 15.0 & 18.0 & -2.6 & -75.0 & 8.3 & 9.3 & -2.2 & -26.9 & 15.8 & -32.9 & -12.4 & \\
\hline 町村型a(維持) & 8 & 3.6 & 5.5 & -4.9 & -15.0 & 2.1 & 0.0 & 0.0 & -47.3 & 23.4 & -34.0 & -15.7 & \\
\hline 町村型 $\mathrm{b}$ (II 期廃校) & 8 & 3.1 & 3.8 & -67.3 & -6.3 & 0.0 & 0.0 & 0.0 & -60.8 & 24.4 & -29.0 & -19.5 & \\
\hline 町村型c(広域) & 2 & 7.5 & 16.0 & -28.6 & -35.4 & 0.0 & 0.0 & -43.8 & -62.8 & -4.3 & -28.8 & -36.1 & \\
\hline 町村型 $\mathrm{d}(\mathrm{V}$ 期廃校) & 7 & 4.0 & 5.1 & -9.5 & 0.0 & -3.6 & 0.0 & -60.2 & -56.8 & 4.5 & -25.3 & -25.9 & \\
\hline 町村型e( I 期分校廃校) & 11 & 3.5 & 4.9 & -9.7 & -95.5 & 0.0 & -3.0 & -15.2 & -55.3 & 6.5 & -22.2 & -33.8 & \\
\hline 町村型f(III期廃校) & 2 & 4.5 & 6.5 & 0.0 & -25.0 & -66.7 & 0.0 & 0.0 & -53.9 & 14.6 & -28.6 & -20.2 & \\
\hline
\end{tabular}

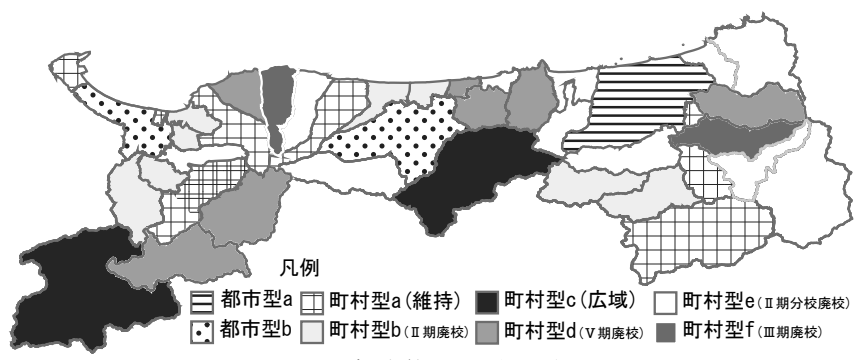

図 4 自治体の類型分布
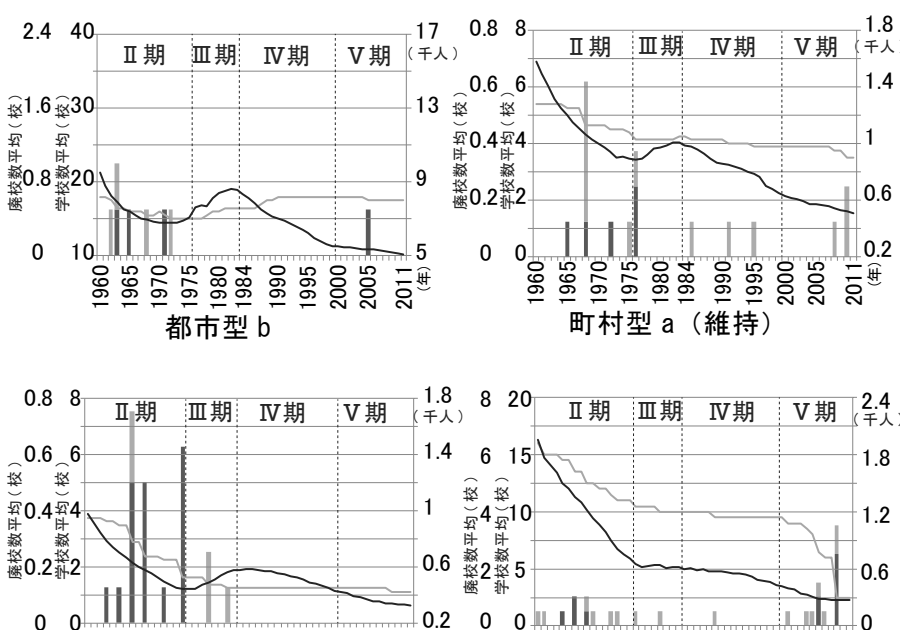

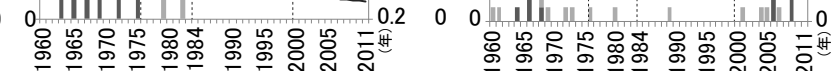
町村型 b (II 期廃校) 町村型 c (広域)

数を所管していた市部では、特に II 期に集中して学校統廃合が行わ れている。一方郡部では、各期を通して廃校が発生しているが、II 期は元々所管学校数の少ない自治体、V 期は比較的所管学校数の多 い自治体での廃校発生が顕著となっている。

\section{3 各自治体の時期別学校増減率（図 3)}

次に各自治体の時期別学校増減率の分布を図 3 に示す。II 期は児 童数の減少が始まり廃校が増加した時期であり、ほぼ県の全域で廃 校が発生していることが分かる。特に分校の減少が顕著であり、県 全域の約半数の自治体で 3 割以上の学校が減少している。一方、III 期は県内の児童数が増加に転じた時期であり、全体的に廃校数は少 なく市部では増加傾向にある。しかし、中山町、郡家町では大規模 な統廃合がおこり 3 割を超える本校が廃校となっている。IV期は再 び児童数が減少に転じた時期であるが、全体的に廃校数は少ない。 $\mathrm{V}$ 期は郡部での学校増減率が-30\%を超える地域が多く見られる。同 時期に行われた平成の大合併との関連で見ると、増減率-30\%を超え る 11 自治体中半数以上の 6 自治体は市町村合併 (現米子市、大山町、 湯梨浜町、鳥取市)による影響を受けていると考えられる。一方で、 平成の大合併時に合併していない自治体も 5 自治体（江府、日野、 日南、岩美、若桜の 5 町）含まれ、いずれも山間部・県境部である。

II 期から V 期にかけての学校増減は、市部と郡部で異なる傾向が 見られる。さらに、郡部内においても学校増減の生じる時期に合併 の影響や山間・県境に起因寸る地域差が生じていることが分かる。

\section{4. 自治体の児童数と廃校数推移の特徵}

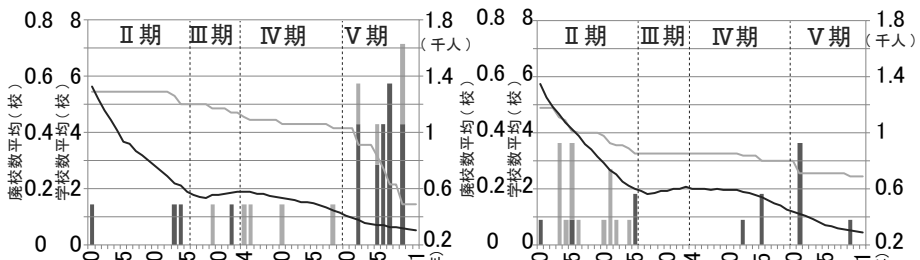

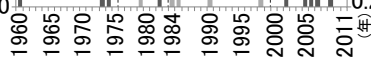
町村型 $\mathrm{d}(\mathrm{V}$ 期廃校 $)$

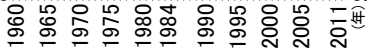
町村型 e (II 期分校廃校)

凡例

口本校廃校数平均 - 分校廃校数平均 一児童数平均—学校数平均 ※図中の学校数は本校・分校の合計数である

図 5 類型別児童・廃校数の推移

校が減少し、II 期から IV 期にかけての学校増減率も-63.2\% と半数以 上の学校が廃校となっており、市部との明確な差異が確認された。

鳥取県全体では、1960 年から 50 年間で、学校増減数-129 校、学 校増減率が-47. 3\%と約 5 割の学校が廃校となっている。多くの学校
4. 1 学校・児童増減率を指標とした自治体の類型化（表 2・図 4-5）

ここからは、廃校発生状況の自治体毎の特徵を明らかにするため、 表 2 上段に示寸 1960 年時学校数、各期の学校 ・児童増減率の 10 変 数注7) を用いてクラスター分析 (ward 法)を行い、41 自治体の巟童・ 廃校数の推移パターンを 8 タイプに分類した。各類型の指標平均值 を表 2、自治体類型分布を図 4 、児童・廃校数推移を図 5 に示寸注 8 )。

\section{2 各類型の特徵}

都市型 a(1 自治体) は、最も多くの学校を所管する鳥取市であり、 II 期にすべての分校と一部の本校で廃校が見られた後、III期に児童 増減率 $20.8 \%$ と増加傾向を示し、第 2 次ベビーブームの影響を大き く受けたタイプであると言える。この間の学校数増加については、 児童数増にともなう小学校の分離等の影響が考えられる注 9)。また、 IV 期の児童増減率は-23.8\%にも関わらず、学校増減率は $16.0 \%$ と増 加の值を示している。これは、III期の児童数急増による影響と合わ せ、都市近郊で住宅地開発等が行われた事に起因する注 ${ }^{10)}$ 。 
表 3 学校規模別本校数・本校増減数の推移

\begin{tabular}{|c|c|c|c|c|c|c|c|c|c|c|c|c|c|c|c|c|}
\hline \multirow{2}{*}{ 児童数 } & \multicolumn{4}{|c|}{ 都市型a } & \multicolumn{4}{|c|}{ 都市型b } & \multicolumn{4}{|c|}{ 町村型a(維持) } & \multicolumn{4}{|c|}{ 町村型b( II 期廃校) } \\
\hline & II 期 & III期 & IV期 & $\mathrm{V}$ 期 & II 期 & III期 & IV期 & $\mathrm{V}$ 期 & II 期 & III期 & IV 期 & $\mathrm{V}$ 期 & II 期 & III期 & IV期 & $\mathrm{V}$ 期 \\
\hline $1 \sim 30$ & & & & & & & & & & & & 1 & 1 & 1 & 1 & 1 \\
\hline $31 \sim 60$ & & 1 & & & & & & & & 1 & 1 & 4 & & & & \\
\hline $61 \sim 120$ & & 3 & 3 & 3 & & 1 & 1 & $4(-1)$ & & 1 & 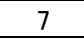 & 1 & $1(-1)$ & & & \\
\hline $121 \sim 240$ & 2 & 4 & 1 & 7 & $3(-2)$ & 6 & $4(+1)$ & 8 & $8(-2)$ & 6 & 4 & 5 & $9(-9)$ & 1 & & 2 \\
\hline $241 \sim$ & 23 & $16(+1)$ & $21(+4)$ & 19 & 28 & $22(+3)$ & $27(+2)$ & 23 & $21(-2)$ & $11(+1)$ & 14 & 9 & 14(-6) & 7 & 8 & 6 \\
\hline 計 & 25 & $25(+1)$ & $25(+4)$ & 29 & $31(-2)$ & $29(+3)$ & $32(+3)$ & $35(-1)$ & $29(-4)$ & $25(+1)$ & 26 & 26 & $25(-16)$ & 9 & 9 & 9 \\
\hline \multirow{2}{*}{ 児童数 } & \multicolumn{4}{|c|}{ 町村型c(広域) } & \multicolumn{4}{|c|}{ 町村型 $\mathrm{d}(\mathrm{V}$ 期廃校) } & \multicolumn{4}{|c|}{ 町村型e(II 期分校廃校) } & \multicolumn{4}{|c|}{ 町村型f(III期廃校) } \\
\hline & II 期 & III期 & IV 期 & $\mathrm{V}$ 期 & II 期 & III期 & IV 期 & $\mathrm{V}$ 期 & II 期 & 正期 & IV 期 & $\mathrm{V}$ 期 & II 期 & III期 & IV期 & $\mathrm{V}$ 期 \\
\hline $1 \sim 30$ & & & 2 & $3(-3)$ & & & 2 & \begin{tabular}{|c|}
$3(-3)$ \\
\end{tabular} & & & & & & & & \\
\hline $11 \sim 60$ & & 3 & 2 & $5(-4)$ & $1(-1)$ & 5 & 4 & $5(-5)$ & & 1 & 1 & $2(-2)$ & & & & \\
\hline $61 \sim 120$ & $2(-2)$ & 5 & 4 & $2(-1)$ & $3(-1)$ & $6(-1)$ & 4 & $4(-4)$ & $1(-1)$ & 11 & $9(-1)$ & $13(-5)$ & & $5(-5)$ & & \\
\hline $121 \sim 240$ & $9(-2)$ & 2 & 2 & & 7 & 10 & 7 & $10(-6)$ & $9(-4)$ & 12 & $13(-3)$ & 11 & 4 & $3(-3)$ & & \\
\hline $241 \sim$ & 4 & 1 & 1 & $1(+1)$ & $17(-1)$ & 4 & 7 & $2(+2)$ & $28(+1)$ & 10 & $11(+1)$ & $5(+1)$ & 5 & $1(+2)$ & 3 & 3 \\
\hline 計 & $15(-4)$ & 11 & 11 & $11(-7)$ & $28(-3)$ & $25(-1)$ & 24 & $24(-16)$ & $38(-4)$ & 34 & $34(-3)$ & $31(-6)$ & 9 & $9(-6)$ & 3 & 3 \\
\hline
\end{tabular}

※表中の数値は、期始の本校数を示す。また、括弧内の数値は各期の本校増減数を示す。

都市型 b (2 自治体) は、鳥取市と規模の比較的小さな境港市を除 く旧市部 2 自治体（米子市・倉吉市）であり、都市型 a と類似した 傾向を示す。II 期の分校学校増減率が-75.0\%と高いが、本校の学校 増減率は-2.6\%と低い。また、IV期には、住宅地開発等にともなう学 校の新設も生じている注 11)。一方、V 期に入り再び本校の廃校が発 生している点で都市型 a と異なっている。

町村型は、各期の学校増減率をもとに、比較的各期共に変化の小 さい a (維持) 型、II 期に本校の廃校が多い b（II 期廃校）型、1960 年時点の所管学校数の多い c (広域) 型、 $\mathrm{V}$ 期に廃校が多い $\mathrm{d}(\mathrm{V}$ 期 廃校）型、II 期に分校の廃校が多い e（II 期分校廃校）型、III期に 廃校が多いf（III期廃校）型の 6 タイプに分類を行った。

町村型 a (維持)（8 自治体）は、各期を通じて学校増減率の変化 が小さな地域となっており、境港市もこの型に含まれる。都市型に 比べ 1960 年時点の所管学校数が少ない点も特徵としてあげられる。 また、2011年までに 1 自治体あたり約 1100 人の児童数減少が見ら れ、大幅な児童減少が生じているが、学校数減少はごく僅かであり、 50 年間で近年まで分校の廃校は見られるが、本校の廃校は 30 校中 II 期の 4 校のみにとどまっている。この 8 自治体には、都市型に隣 接し面積も小さな 3 自治体注 ${ }^{12)}$ も該当することから、所管学校数が 少なく、 $\mathrm{V}$ 期の児童数減少も比較的緩やかであるため、本校の廃校 は少ない。

町村型b (II 期廃校) (8 自治体) は、II 期の本校学校増減率が- $67.3 \%$ と各タイプの中で最も大きな值を示し、多くの廃校が発生している。 また、第 2 次ベビーブームの影響を受け、IIII期に類型の中で最も高 い $24.4 \%$ 览童数増加が生じているが、学校の新設等も行われず、 II 期の学校減少以降、平均学校数が早期に 1 校程度になった状態で 現在に至っている注 13)。この 8 自治体の内、4つは米子市隣接、2つ は倉吉市隣接、2 つは鳥取市南部に近接することから、II 期の人口 流失がおこった後に一転してIII期では宅地化が進んだ結果、III期以 降の廃校がない状態になっている。

町村型 c（広域）（2 自治体）は、1960 年時点で行政区域が広範囲 に及び所管学校数の多い日南町（1959 年 5 村合併で誕生）と三朝町 （1953 年 5 村合併で誕生）の 2 自治体である。児童・廃校数の推移 をみると II 期の児童数減少が顕著であり、II 期だけで 1 自治体あた り 1300 人近くの児童が減少している。それと合わせ、II 期に学校増
減率が本校で-28.6\%、分校で-35.4\%の值を示しており、児童数減少 にともなう廃校が広域的に発生していたと考えられる。その後は緩 やかな児童数減少を経て、V期に学校増減率が本校で-43.8\%と高い 值を示している。2 自治体共に平成期には市町村合併を行っていな いが、児童減少に伴い特に日南町では近年統廃合を進めている注 14)。

町村型 $\mathrm{d}(\mathrm{V}$ 期廃校) (7 自治体) は、 $\mathrm{V}$ 期の本校学校増減率が- $60.2 \%$ と著しく高い值を示し、 $\mathrm{V}$ 期に入り平均学校数が 1 校程度まで急速 に減少している注 ${ }^{15)}$ 。览童数推移については、II 期の-56.8\%の急激 な児童数減少以降、多少の増加がみられるものの緩やかに児童減少 が続いており、これは後述する町村型 e と類似した傾向を示してい る。7 自治体中、平成に市町村合併を行ったのが 5 自治体、合併を 行わなかったのが 2 自治体だが、いずれも児童減少に応じて統廃合 を進めている。

町村型 e（II 期分校廃校）（11 自治体）は、II 期の分校学校増減率 が-95.5\%とほぼ全ての分校が廃校となっており、この点は都市型に 近、特徴といえる。しかし、児童数の減少も高い值を示しており、 III期を除き各期で本校の廃校が発生している。11 自治体中の 7 自治 体が県東部にあり、特に兵庫県と接する自治体の児童減少が著しい。

町村型 $\mathrm{f}$ (III期廃校) (2 自治体) は、III期の本校学校増減率が-66.7\% を示し、本校の廃校が他タイプと異なる時期に集中している点が特 徵としてあげられる注 ${ }^{16)}$ 。览童数の増減は他の町村型と類似した傾 向を示すが、IV期以降本校の廃校は見られない。

\section{5. 学校規模と本校増減数の関係（表 3)}

類型別の学校規模別本校数 - 本校増減数の推移を表 3 に示す。県 全体の傾向として、児童数の多い本校での減少が多い。児童数別に 見ると、本校は $1 \sim 30$ 人規模の学校で 6 校、31～60 人規模で 12 校、 $61 \sim 120$ 人規模で 23 校、121 240 人規模で 30 校 $(-31$ 校、 +1 校 $)$ それぞれ減少しており、241 人以上の規模でのみ 10 校の増加 $(-9$ 校、+19 校）と 241 人以上を抱える大規模校を除けば、児童数が多 い本校ほど廃校が発生していることが分かる。大規模校で本校が増 加しているのは、小・中規模校の統合が行われたことが要因と考え られる。

また類型別に見ると、都市型 a はIII期と IV 期に本校数が増加して おり、いずれも 241 人を超える大規模校である。ただし、IV期から 
$\mathrm{V}$ 期にかけて規模の縮小が生じており、各本校で児童数が減少して いる。一方、都市型 b は、II 期と V 期に本校の減少が生じているが、 III 期と IV 期は都市型 a 同様、大規模校が増加している。また IV 期か $ら \mathrm{~V}$ 期にかけての学校規模の縮小も顕著である。町村型 a（維持） は、241 人以上を抱える大規模校が II 期から V 期にかけ、21 校から 9 校まで減少している。また $\mathrm{V}$ 期には、60人以下の小規模校の割合 が増加しており、本校数は維持できているものの、学校単位での児 童数減少が顕著となっている。町村型 b (II 期廃校) は、II 期に本校 の減少が集中しており、121 人以上の規模の本校が 23 校から 8 校に 減少している。町村型 $\mathrm{c}$ (広域) は、II 期に 15 校中 4 校、V 期に 11 校中 7 校が減少している。特にV 期は、小規模校の本校数減少と合 わせ大規模校が 1 校増加しており、小・中規模の小学校で統廃合が 行われている。町村型 $\mathrm{d}$ ( $\mathrm{V}$ 期廃校) は、 $\mathrm{V}$ 期の本校数増減が顕著で あり, 240 人以下の本校が各規模とも減少しており、特に 120 人以 下の本校は無くなっている。それと合わせ 241 人以上の規模で僅か に増加が見られる事から, 大規模な小学校の統合・集約化が図られ ている。町村型 $\mathrm{e}$ (II 期分校廃校) は、IIII期を除き各期でそれぞれ比 較的規模の小さな本校の数が減少し、それにともない 241 人以上の 大規模校が増加している。ただし、II 期から V 期にかけて見ると、 大規模校の総数自体は減少しており、統廃合等を経て 1 度は大規模 校化した学校がその後、児童数減少の影響を受け規模が縮小してき ている。町村型 $f$ (III期廃校) は、III期に学校数の増減が集中してお り、240人以下の学校がすべて無くなり、241人を超える大規模校の みとなっている。この間に大規模な統廃合が行われ、いずれの学校 も 241 人以上の規模を保ったまま現在に至っている。

\section{6. 結論}

本報告では鳥取県の小学校の児童·学校数推移資料(1949-2011) をもとに、自治体類型毎の廃校動向について検討を行い、以下の知 見を得た。

1 ）少子高齢化が進み、廃校率が全国で 5 番目に多い鳥取県では、 小学校数が 1960 年から 50 年間で半数以下にまで減少している。 児童数の減少が進んだ II 期の廃校数は多く、II 期中に分校数も半 減している。こうした中でも鳥取県では中山間地域が多いため、 分校数はIV期までは比較的緩やかに減少しており、分校数の減少 が急な山口県とは異なる特徵が見られた。これらの多くはV 期ま でに廃校になっている。

2 ) 鳥取県は、1960 年時点で市町村数が 41 と比較的小規模な都道 府県ではあるが、児童・学校数の推移において、市部と郡部、ま た郡部内でも異なる傾向を示す自治体が混在している。

3 ) 市部は、1960 年以降、各学校で児童数は減少しているものの、 中・大規模を維持しており統廃合は比較的少ない。一方、郡部は 1960 年時点で一部の自治体を除き、各自治体の抱える学校数が少 なく、その後の学校数減少も顕著である。ただし、学校の統廃合 が進行する時期には差異が確認された。そこで、学校・児童増減 率を指標として自治体の類型化を行うと、計 8 のタイプに細分化 することが出来る。

4 ）都市型は、計 4 市の内 3 市（鳥取市・米子市・倉吉市）が属す るタイプであり、II 期に一部の本校と大部分の分校が廃校になっ た後は、学校数は増加傾向にある。1960 年時点での所管学校数の
差により、都市型 a と都市型 $\mathrm{b}$ に区分寸ることが出来る。

5 ) 町村型は、廃校の集中する時期に違いが生じている 4 タイプの 他、比較的各期共に変化の小さい維持型、さらに 1960 年時点での 所管学校数に特徵のある広域町村型を含め計 6 タイプに分類する ことが出来た。

6 ）町村型 a (維持) の境港市を含む 7 町村は、各期の廃校数は僅 かであり、学校運営を比較的維持出来ているため、維持型と位置 づけている。ただし、II 期から V 期にかけて学校数を増加・維持 出来ている自治体であっても、学校規模で見ると各学校が縮小傾 向にあり、県内での児童数減少も進行している事から、今後大規 模な再編が進められることが推察される。

7 ) 町村型 c(広域)に分類することが出来た 2 町（三朝町・日南町） については、1950 年代の合併によって 1960 年時点で行政区域が 広範囲に及んでおり、 $\mathrm{V}$ 期の平成の大合併期の影響を受けていな い。また、それにともない所管学校数も多くなっている。II 期に 統廃合が進められた後は、学校数の増減は分校廃校のみの僅かな ものであったが、近年急速に大規模な統廃合が進められている特 徵的な自治体である。

8 ）上記 2 つ以外の町村型では、廃校の集中する時期別に II 期・III 期・V 期と大きく 3 つの時期に区分することが出来、さらに II 期 に生じる廃校の傾向は、本校が中心のタイプ (町村型 b) と分校 が中心のタイプ (町村型 e) とに分けることが出来る。町村型 b については、II 期の統廃合により、本校 1 校と分校とで継続して いる自治体が大部分となっている。町村型 e については、分校の 大部分が II 期に廃校となった点で特徴がある他、学校規模の再編 が段階的に生じている。町村型 $\mathrm{d}$ は、 V 期の統廃合が著しく、各 自治体所管の学校数が短期間で 1 校に近づいている。町村型 $\mathrm{f}$ は、 児童数の増加するIII期に統廃合が顕著となっており、自治体数は 少ないが他とは特徵の異なるタイプである。郡部の学校数の推移 には、自治体毎の差異が顕著に表れており、今後地理条件や統廃 合における計画の有無等を含めた詳細な検証が必要となる。また、 いずれのタイプでも览童数の減少が都市部よりも顕著であり、近 年さらなる統廃合が進められることが推察される。

\section{7. 今後の展開}

今後は本報告を含めて中国 5 県の公立小学校・中学校の廃校動向 を横断的に明らかにする予定である。これによって中国地方におけ る全体的な巟童数 - 廃校数の動向や自治体類型の把握と共に、中国 5 県に跨がる中国山地・県境部において児童数の減少と廃校数の増 加が進んだ特徵的な自治体等における政策的理由や廃校事例に関す る詳細な分析も予定している。

\section{注}

注 1 ） 1953 年「町村合併促進法」により 1961 年までに市町村数はほぼ $1 / 3$ となる。1956 年「公立小・中学校の統合方策 (旧文部省通達)」により統 廃合が進むが、1973 年同省通達によって統廃合が沈静化する。また、1999 年「市町村合併特例新法」により 2010 年までに市町村数はほぼ半減した。 注 2 ) 中国 5 県における横断的な研究とする意義としては、同一指標によっ て山陽地方と山陰地方、都市地域と農山漁村地域の学校統廃合動向の比較 を可能にし、特に中国 5 県に跨がる中国山地・県境部における動向を捉え ることができると考えている。 
注 3 )「教育行政便覽」は 1959 年以前の版が作成されていないため、「鳥取県 教職員録」を閲覧し、資料が保管されている 1949 年から 1959 年までの学 校基本情報を収集した。

注 4 ）鳥取県教育庁教育政策課の提供資料により、「教育行政便覧」の 1960 -2011 年版を収集し、県内公立小学校の学校数·生徒数·廃校時期等の基本 情報を収集した。

注 5 ）「教育行政便覧」では学校間の具体的統廃合パターンの確定が困難なた め、市町村史等の資料収集とヒアリングにより各校の統廃合と新設の経緯 を調查した。本論では、 $\mathrm{A}$ 校に $\mathrm{B}$ 校が統合され名称変更がない場合、 $\mathrm{AB}$ 校 が統合され名称変更されるが既存 A 校の敷地・校舎を利用する場合には、A 校を「統合校」、B 校を「廃校」と定義する。 $\mathrm{AB}$ 校が統合され名称変更と校 舎の建替え・新設が行われる場合、児童数の多い A 校を「統合校」、B 校を 「廃校」と定義する。 $\mathrm{A}$ 校から B 校が分離新設される場合、 $\mathrm{A}$ 校を「分離校」、 新規に建設された B 校を「新設校」と定義する。また、鳥取県では、小学 校の統合時、C 小学校と D 小学校が統合して E 小学校と名称が変更される 際、E小学校 C 校舎、E小学校 D 校舎のように、新校舎が建つまで仮校舎と して使用する事例がみられた。その場合は、仮校舎としての運営が始まっ た年を区切りとして廃校数・新設数に加算している。

なお、鳥取県では小学校が 1960 年以降廃校後に養護学校に転用される事 例が 4 例みられたが，本論の分析においては、廃校となった時点で集計か らは除外している。

注 6 ）鳥取県教職員録には分校の学校基本情報が記載されていないため、分 析は 1960 年以降について行った。

注 7 ) 自治体の類型化の前提として、自治体毎に 1950 年代の旧町村の区域数 や谷筋集落の存在形態が多様であるため、自治体面積や人口密度は直接の 指標としては入れていない。ここでの類型化では、1960 年時点の旧市町村 区域における学校数（本校数+分校数）を指標に入れることによって、自治 体区域の広がりや人口密度に関する要素も含まれていると考えている。

注 8 ) 図 5 では、都市型 a、町村型 $\mathrm{f}$ (III期廃校) は省略し、より特徴的な都市 型 b、町村型 a 町村型 e までを図示する。

注 9 ) 都市型 a の鳥取市では、吕期に稲葉山小学校、面影小学校から、岩倉 小学校が分離新設している。これは、児童数急増によるものである。

注 10) 都市型 a の鳥取市では、IV期に美保小学校から美保南小学校が分離新 設している。これは、ベビーブームによる人口急増のためである。

注 11）都市型 $\mathrm{b}$ の米子市では、IV期に日新小学校から尚徳小学校が分離新設 している。分離新設の理由はベッドタウン化による団地造成を受けて、児 童数が急増したためである。その後、 $\mathrm{V}$ 期になり、児童数の減少と共に日 新小学校は尚徳小学校へ統合され、廃校となった。

注 12） 3 自治体は、米子市に隣接する境港市・日吉津村、鳥取市に 1963 年編 入された津ノ井村が該当する。いずれも自治体面積が狭く、都市型自治体 一の通勤圈に位置する。

注 13）米子市隣接の西伯は 1967 年、会見は 1965 年、淀江は 1969 年に各 1 小学校へ統合した。倉吉市隣接の北条は 1961 年、大栄は 1975 年に各 1 小 学校へ統合した。鳥取市南部近接の用瀬は 1969 年、佐治は 1975 年に各 1 小学校へ統合した。

注 14）日南町は平成期には市町村合併を行っていないが、児童数の減少に伴 い、V 期中に 2 段階にわたって大規模な統廃合を行っている。2006 年に 3 本校・1 分校を統合して山の上小学校とした。さらに、2009 年にも山の上 小学校を含む 6 校を統合して日南小学校としている。

注 15) 町村型 $\mathrm{d}(\mathrm{V}$ 期廃校) の自治体例として、名和町は 2005 年に大山町・中 山町と合併したが、その後 2006 年から 2010 年にかけて、2 本校・ 2 分校を 統合して名和小学校としている。

注 16) 町村型 $\mathrm{f}$ (III期廃校) の 2 自治体は、中山町と郡家町である。いずれも IIII期中に今後の学校運営を予測して統廃合を行っている。中山町では 1977 年に 3 小学校を統合し、中山小学校が新設されている。郡家町では 1981 年 に 3 小学校ごとの計 6 校を統合し、西小学校と東小学校の 2 校が新設され ている。

\section{参考文献}

1) 古川義秀：鳥取県内公立小中学校統廃合の状況，とっとり地域連携・総 合研究センター, 2011 年度事業実施報告書, pp. 6-11, 2012.3

2 ) 藤野哲生・藍澤宏・菅原麻衣子 : 公立小学校廃校の要因とその課題に関 する研究, 日本建築学会計画系論文集, No649, pp. 579-585, 2010.3
3 ) 斎尾直子 : 公立小中学校の統廃合プロセスと廃校舎利活用に関する研究, 日本建築学会計画系論文集, No. 627,pp. 1001-1006, 2008.5

4 ）野沢英希 - 谷口元 - 恒川和久 - 太幡英亮 : 廃校のある地域属性の特徽と 再利用に関寸る研究: 愛知県・岐阜県・ 三重県の事例を通して, 日本建築学 会計画系論文集, No. 674,pp. 865-872,2012.4

5 ) 足名伸介 ・溝㴊匠 - 吉村彰 : 廃校施設の有効活用に関寸る調查研究その 1-3, 日本建築学会大会学術講演梗概集, E-1 分冊, pp. 101-106, 2005.9

6 ) 山本幸子・中園眞人・清水聡 士 : 廃校となった公立小中学校施設の運用状 況，日本建築学会技術報告集,第 18 巻 第 38 号, pp. 351-354, 2012.02

7 ) 栗崎真一郎・横山俊祐：学校の活性化からみた小学校の統廃合の評価一 広島県を対象とした統廃合の実態と課題, 日本建築学会計画系論文集, No. 695 , pp. 97-104, 2014.1

8 ) 安田隆子 : 学校統廃合-公立小中学校に係わる諸問題-, 調査と情報 第 640 号, 2009. 4

9 ) 中園眞人・初崎竜太郎・清水聡 士 ・山本幸子 : 山口県における公立小学校 の児童·学校数の推移(1949-2011), 日本建築学会技術報告集, 第 20 巻 第 44 号, pp. 237-240, 2014. 2

[2014 年 6 月 18 日原稿受理 2014 年 8 月 12 日採用決定］ 